\title{
Role of Coronary Collaterals in Off-Pump and On-Pump Coronary Bypass Surgery
}

Hendrik M. Nathoe, Erik Buskens, Erik W.L. Jansen, Willem J.L. Suyker, Pieter R.

Stella, Jaap R. Lahpor, Wim-Jan van Boven, Diederik van Dijk, Jan C. Diephuis, Cornelius Borst, Karel G.M. Moons, Diederick E. Grobbee and Peter P.T. de Jaegere Circulation 2004;110;1738-1742; originally published online Sep 20, 2004; DOI: 10.1161/01.CIR.0000143105.42988.FD

Circulation is published by the American Heart Association. 7272 Greenville Avenue, Dallas, TX 72514

Copyright $@ 2004$ American Heart Association. All rights reserved. Print ISSN: 0009-7322. Online ISSN: $1524-4539$

The online version of this article, along with updated information and services, is located on the World Wide Web at: http://circ.ahajournals.org/cgi/content/full/110/13/1738

Subscriptions: Information about subscribing to Circulation is online at http://circ.ahajournals.org/subsriptions/

Permissions: Permissions \& Rights Desk, Lippincott Williams \& Wilkins, 351 West Camden Street, Baltimore, MD 21202-2436. Phone 410-5280-4050. Fax: 410-528-8550. Email: journalpermissions@1ww.com

Reprints: Information about reprints can be found online at http://www.lww.com/static/html/reprints.html 


\section{Role of Coronary Collaterals in Off-Pump and On-Pump Coronary Bypass Surgery}

Hendrik M. Nathoe, PhD; Erik Buskens, PhD; Erik W.L. Jansen, PhD; Willem J.L. Suyker, MD; Pieter R. Stella, MD; Jaap R. Lahpor, PhD; Wim-Jan van Boven, MD; Diederik van Dijk, MD, PhD; Jan C. Diephuis, MD; Cornelius Borst, PhD; Karel G.M. Moons, MD; Diederick E. Grobbee, MD, PhD; Peter P.T. de Jaegere, MD, PhD

Background - Collaterals limit infarct size, preserve viability, and reduce mortality in patients with acute myocardial infarction. In patients with stable coronary disease, collaterals are associated with less angina and ischemia during angioplasty and fewer ischemic events during follow-up. The role of collaterals has not been studied in patients undergoing off-pump or on-pump bypass surgery.

Methods and Results - The population consisted of the 281 patients randomized to off-pump or on-pump CABG in the Octopus Study. Collaterals were defined on the baseline angiogram with the Rentrop score and were present in $49 \%$ and $51 \%$ of the patients in the off-pump and on-pump group, respectively. Perioperative myocardial infarction was defined by a creatine kinase-MB to CK ratio $>10 \%$ and occurred in $18.2 \%$ in the off-pump group and $32.5 \%$ in the on-pump group. The unadjusted OR of perioperative myocardial infarction in the presence of collaterals was 0.31 (95\% CI 0.17 to 0.84 ) in the off-pump group and 1.06 (95\% CI 0.29 to 3.85) in the on-pump group After adjustment for age, gender, hypertension, hypercholesterolemia, diabetes, multivessel disease, ventricular dysfunction, incomplete revascularization, and ischemic time, the OR was 0.34 (95\% CI 0.14 to 0.84) in the off-pump group and 1.28 (95\% CI 0.30 to 5.40 ) in the on-pump group, respectively. Kaplan-Meier estimates of event-free survival at 1 year were $87 \%$ in patients with and $69 \%$ in those without collaterals after off-pump CABG. These estimates were $66 \%$ and $63 \%$, respectively, after on-pump CABG.

Conclusions - Collaterals protect against perioperative myocardial infarction during off-pump surgery but not during on-pump surgery and are associated with a better 1-year event-free survival. (Circulation. 2004;110:1738-1742.)

Key Words: bypass — collateral circulation a surgery m mocardial infarction

$\mathrm{T}$ he presence of collaterals may limit infarct size, preserve viability, and reduce long-term mortality in patients with acute myocardial infarction. ${ }^{1-4}$ In patients with stable coronary artery disease, collaterals are associated with less angina and ischemia during angioplasty (PCI)-induced coronary occlusion and with fewer ischemic events during followup..$^{5-7}$ The protective role of collaterals has not been studied in patients who undergo coronary bypass surgery.

Recently, off-pump bypass surgery (off-pump CABG) has been reintroduced in clinical practice to address the limitations of conventional surgery (on-pump CABG). During the latter, complete ischemic cardiac arrest is induced in combination with the use of cardiopulmonary bypass for construction of the anastomoses. During off-pump CABG, the anastomoses are constructed on the beating heart while the target coronary is occluded for $\approx 15$ minutes. ${ }^{8}$ We hypothesized that as a result of the different nature of the 2 operations, collaterals may protect patients against perioperative myocardial damage after off-pump CABG but not after on-pump CABG. For this purpose, we studied the relationship between collaterals and perioperative myocardial infarction (MI) in patients who were enrolled in a randomized comparison between off-pump and on-pump CABG. ${ }^{9}$ Subsequent ischemic events during 1-year follow-up were also assessed.

\section{Methods}

\section{Study Population}

The population consisted of the 281 patients enrolled in the Octopus Study, described elsewhere. ${ }^{9}$ In brief, patients with stable or unstable angina (Braunwald class I or II, B) with normal or moderately impaired ventricular function were randomly assigned to on-pump or off-pump CABG. Patients were eligible if referred for first-time isolated $\mathrm{CABG}$ and if the off-pump procedure was technically feasible. Patients were excluded in case of emergency or concomitant major surgery, Q-wave myocardial infarction in the last 6 weeks,

Received January 15, 2004; de novo received March 23, 2004; revision received May 28, 2004; accepted June 2, 2004.

From the Departments of Cardiology, Heart Lung Center Utrecht (H.M.N., P.R.S., C.B., P.P.T.d.J.), Anesthesiology (D.v.D., J.C.D.), Cardiothoracic Surgery (E.W.L.J., J.R.L., W.-J.v.B.), and The Julius Center for Health Science and Primary Care (E.B., K.G.M.M., D.E.G.), Utrecht, The Netherlands, and Isala Clinics, Department of Cardiothoracic Surgery (W.J.L.S.), Zwolle, The Netherlands.

Correspondence to Peter de Jaegere, Department of Cardiology, Thoraxcenter, Erasmus Medical Center Rotterdam, Dr Molewaterplein 40, 3015 GD Rotterdam, The Netherlands. E-mail p.dejaegere@erasmusmc.nl

(C) 2004 American Heart Association, Inc. 
TABLE 1. Baseline and Perioperative Characteristics of Patients Undergoing Off-Pump or On-Pump Bypass Surgery

\begin{tabular}{|c|c|c|c|c|}
\hline \multirow[b]{2}{*}{ Variables } & \multirow[b]{2}{*}{$\begin{array}{l}\text { All Patients } \\
(\mathrm{n}=281)\end{array}$} & \multicolumn{2}{|c|}{ Collaterals } & \multirow[b]{2}{*}{$P$} \\
\hline & & $\begin{array}{l}\text { Present } \\
(n=129)\end{array}$ & $\begin{array}{c}\text { Absent } \\
(n=152)\end{array}$ & \\
\hline \multicolumn{5}{|l|}{ Demographics } \\
\hline Mean age, y & 61.3 & 60.5 & 61.9 & 0.17 \\
\hline Male gender, \% & 68 & 69 & 68 & 0.83 \\
\hline \multicolumn{5}{|l|}{ Cardiovascular risk factors, \% } \\
\hline History of smoking & 73 & 72 & 74 & 0.77 \\
\hline Hypertension & 42 & 39 & 45 & 0.30 \\
\hline Hypercholesterolemia & 68 & 74 & 64 & 0.07 \\
\hline Diabetes & 13 & 10 & 15 & 0.21 \\
\hline Obesity (body mass index $>30 \mathrm{~kg} / \mathrm{m}^{2}$ ) & 15 & 14 & 15 & 0.78 \\
\hline Antecedents of cardiovascular disease, $\%$ & 57 & 54 & 59 & 0.47 \\
\hline Stable angina, \% & 75 & 78 & 72 & 0.34 \\
\hline Serum creatinine, mg/dL & 1.02 & 1.01 & 1.04 & 0.99 \\
\hline \multicolumn{5}{|l|}{ Angiographic characteristics, \% } \\
\hline Multivessel coronary disease & 74 & 77 & 71 & 0.28 \\
\hline Moderately impaired left ventricle & 22 & 26 & 18 & 0.08 \\
\hline \multicolumn{5}{|l|}{ Perioperative characteristics, \% } \\
\hline Off-pump surgery & 51 & 49 & 52 & 0.51 \\
\hline On-pump surgery & 49 & 51 & 48 & 0.51 \\
\hline Incomplete revascularization & 16 & 16 & 14 & 0.41 \\
\hline Myocardial infarction & 26 & 18 & 32 & 0.05 \\
\hline
\end{tabular}

Antecedents of cardiovascular disease are the sum of previous stroke, Ml, peripheral vascular disease, and coronary revascularization. See text for other definitions.

or poor left ventricular function. The goal of surgery was to obtain complete arterial revascularization. On-pump CABG was performed with cardiopulmonary bypass in combination with cold crystalloid cardioplegia for myocardial protection. Off-pump CABG was performed with the use of the Octopus cardiac stabilizer. ${ }^{9}$

\section{Coronary Collaterals}

Collaterals were defined by visual assessment of the baseline angiogram with the Rentrop criteria ( 0 , no filling of collaterals; 1 , filling of collaterals without any filling of the epicardial artery; 2, partial filling of the epicardial artery; and 3, complete filling of the epicardial artery). ${ }^{10}$ Collaterals were considered present in case of filling of the epicardial artery (Rentrop $>1$ ). The angiograms were graded in random order by 2 cardiologists who were blinded as to treatment assignment and clinical data. The reproducibility of the Rentrop score has been described as high $(\kappa=0.85,95 \%$ CI 0.77 to 0.93). ${ }^{11}$

\section{Perioperative MI and Cardiac Outcome at 1 Year}

Perioperative MI was defined by a creatine kinase isoenzyme (CK-MB) to total creatine kinase $(\mathrm{CK})$ ratio $>10 \%$ occurring within 48 hours after CABG. ${ }^{12,13}$ In accordance with the Octopus Study protocol, CK-MB and CK enzyme activity was determined before and $2,4,8,12$, and 20 hours after CABG, and additionally when necessary. CK-MB:CK ratio was calculated by dividing CK-MB by the total CK activity at each time point.

Cardiac outcome at 1 year was defined by the composite of all-cause death, nonfatal stroke, nonfatal MI (perioperative or follow-up), and repeat revascularization (PCI or CABG). Death was considered cardiac unless otherwise documented; stroke was defined as focal brain injury that persisted for $>24$ hours, combined with an increase in handicap of at least 1 grade on the Rankin scale. After 48 hours after $\mathrm{CABG}$, a non-Q-wave MI was defined by a CK-MB to total $\mathrm{CK}$ ratio $>10 \%$ and a $\mathrm{Q}$-wave $\mathrm{MI}$ as the appearance of new pathological Q waves.9,12,13 All events were evaluated and adjudicated by an independent Clinical Event Committee.

\section{Data Analysis}

The association between collaterals and perioperative MI was determined by calculating the crude OR for patients who underwent off-pump and on-pump CABG, separately. Multivariate regression analysis was used to correct the unadjusted ORs for variables that were considered confounders of the association examined. Distinction was made between patients with and without collaterals to identify potential determinants of collateral presence. The contribution of putative indicators was analyzed by univariate logistic regression analysis. A $\chi^{2}$ or Student $t$ test was used to discern statistically significant differences. All reported probability values were 2 -sided. A probability value $<0.05$ was considered statistically significant.

The relation between collaterals and 1-year outcome was studied by calculating event-free survival, since the time of randomization, by the Kaplan-Meier method. Kaplan-Meier curves were constructed for both groups with distinction within each group between patients with and without collaterals. Probability values were calculated by the log-rank test. All data were analyzed with SPSS version 10.0.

\section{Results}

A total of 281 patients were randomized to off-pump CABG $(n=142)$ and on-pump CABG $(n=139)$. Seven patients whose surgeries were converted before the operation ( 2 from off-pump to on-pump, 5 from on-pump to off-pump) were analyzed according to the received treatment. Eight patients 
TABLE 2. Cardiovascular Events up to 1 Year After Off-Pump and On-Pump Bypass Surgery

\begin{tabular}{|c|c|c|c|c|c|c|}
\hline \multirow[b]{2}{*}{ Event } & \multicolumn{3}{|c|}{ Off-Pump Surgery ( $n=132$ ) } & \multicolumn{3}{|c|}{ On-Pump Surgery $(n=117)$} \\
\hline & In-Hospital & Follow-Up & 1 Year & In-Hospital & Follow-Up & 1 Year \\
\hline \multicolumn{7}{|l|}{ All events: $<48$ hours* } \\
\hline Ml, perioperative & $24(18.2)$ & $\ldots$ & $24(18.2)$ & $38(32.5)$ & $\ldots$ & $38(32.5)$ \\
\hline \multicolumn{7}{|l|}{ All events: 48 hours to 1 year* } \\
\hline Death, all-cause & $0(0.0)$ & $2(1.5)$ & $2(1.5)$ & $1(0.9)$ & $1(0.9)$ & $2(1.7)$ \\
\hline Stroke & $1(0.8)$ & $0(0.0)$ & $1(0.8)$ & $1(0.9)$ & $0(0.0)$ & $1(0.9)$ \\
\hline Ml, other & $0(0.0)$ & $0(0.0)$ & $0(0.0)$ & $0(0.0)$ & $2(1.7)$ & $2(1.7)$ \\
\hline Coronary reintervention & $1(0.8)$ & $5(3.8)$ & $6(4.5)$ & $0(0.0)$ & $4(3.4)$ & $4(3.4)$ \\
\hline All events, cumulative & $2(1.5)$ & $7(5.3)$ & $9(6.8)$ & $2(3.3)$ & $7(6.0)$ & $9(7.7)$ \\
\hline \multicolumn{7}{|c|}{ First event: operation to 1 year† } \\
\hline Any first event & $24(18.2)$ & $2(1.5)$ & $26(19.7)$ & $38(32.5)$ & $4(3.4)$ & $42(35.9)$ \\
\hline Free from any first event & $\ldots$ & $\ldots$ & $106(80.3)$ & $\ldots$ & $\ldots$ & $75(64.1)$ \\
\hline
\end{tabular}

in the off-pump group were excluded from analysis (1 conversion to PCI before the operation and 7 to on-pump CABG during the operation). Another 24 patients were excluded because of missing CK-MB:CK values. Therefore, 249 patients (132 off-pump and 117 on-pump) were included in the analysis.

Baseline characteristics of the total population are summarized in Table 1. Most patients were male, with a mean age of 61 years and preserved ventricular function. Multivessel disease was present in $74 \%$ of the patients $(50 \%$ with double-vessel disease and $24 \%$ with triple-vessel disease). Collaterals were present in $49 \%$ of patients in the off-pump group and $51 \%$ of patients in the on-pump group. The mean number of grafts per patient was 2.4 in the off-pump group and 2.6 in the on-pump group. Complete arterial revascularization was achieved in $86 \%$ of patients in the off-pump group and $80 \%$ of those in the onpump group. Perioperative MI occurred in $18.2 \%$ of the patients in the off-pump group (CK-MB, median value of the area under the curve 164 units/L) and in $32.5 \%$ of the on-pump group (CK-MB, median value of the area under the curve 277 units/L; Table 2).

Protection of collaterals against perioperative MI was only found in patients who underwent off-pump CABG and not in those who underwent on-pump CABG (Table 3). The unadjusted ORs of perioperative MI in the presence of collaterals were 0.31 (95\% CI 0.17 to 0.84 ) in the off-pump group and 1.06 (95\% CI 0.29 to 3.85) in the on-pump group (Table 3). After adjustment for baseline and perioperative variables that

TABLE 3. Unadjusted and Adjusted Risk of Perioperative MI in Relation to Presence of Collaterals

\begin{tabular}{|c|c|c|c|c|}
\hline \multirow[b]{2}{*}{ Variables } & \multicolumn{2}{|c|}{$\begin{array}{l}\text { Off-Pump Surgery } \\
\quad(n=132)\end{array}$} & \multicolumn{2}{|c|}{$\begin{array}{l}\text { On-Pump Surgery } \\
\quad(n=117)\end{array}$} \\
\hline & OR $(95 \% \mathrm{Cl})$ & $P$ & OR $(95 \% \mathrm{Cl})$ & $P$ \\
\hline Presence of collaterals, unadjusted & $0.31(0.17-0.84)$ & 0.01 & $1.06(0.29-3.85)$ & 0.93 \\
\hline \multicolumn{5}{|l|}{ Presence of collaterals, adjusted for: } \\
\hline Age & $0.43(0.21-0.89)$ & 0.02 & $1.07(0.29-3.91)$ & 0.92 \\
\hline Male gender & $0.34(0.17-0.75)$ & 0.01 & $1.13(0.31-4.17)$ & 0.85 \\
\hline History of hypertension & $0.40(0.20-0.85)$ & 0.01 & $1.01(0.29-3.84)$ & 0.93 \\
\hline History of hypercholesterolemia & $0.40(0.20-0.81)$ & 0.01 & $1.28(0.35-4.75)$ & 0.71 \\
\hline Diabetes & $0.40(0.19-0.80)$ & 0.01 & $1.16(0.32-4.24)$ & 0.83 \\
\hline Multivessel coronary disease & $0.38(0.18-0.77)$ & 0.01 & $1.06(0.29-3.87)$ & 0.93 \\
\hline Moderately impaired left ventricle & $0.40(0.20-0.81)$ & 0.01 & $1.02(0.28-3.78)$ & 0.97 \\
\hline Intraoperative ischemic time* & $0.43(0.20-0.93)$ & 0.03 & $1.18(0.32-4.32)$ & 0.80 \\
\hline Incomplete revascularization & $0.46(0.23-0.94)$ & 0.03 & $1.19(0.33-4.31)$ & 0.79 \\
\hline All variables mentioned above & $0.34(0.14-0.84)$ & 0.02 & $1.28(0.30-5.40)$ & 0.74 \\
\hline
\end{tabular}


were considered confounders of the examined association, the ORs were 0.34 (95\% CI 0.14 to 0.84 ) and 1.28 (95\% CI 0.30 to 5.40), respectively (Table 3).

The Kaplan-Meier estimates of the occurrence of any first event in patients with and without collaterals are depicted in the Figure. The presence of collaterals was associated with a significantly lower rate of any first event in the off-pump group (13\% versus $31 \%, P=0.01)$ but not in the on-pump group (34\% versus $37 \%, P=0.79)$.

\section{Discussion}

The main finding of this study is that collaterals offer protection in terms of fewer perioperative MIs in patients who undergo off-pump CABG but not in those who undergo on-pump CABG. This finding must be viewed and interpreted in the context of the population, methods of assessment, and analysis.

The baseline characteristics and events during the follow-up period, in particular, disclose that this analysis concerns a low-risk population. Despite this, a protective effect from collaterals was observed in the off-pump group. In the present population, this effect was restricted to a reduction in perioperative MI. Perioperative MI was the most frequent and virtually the only clinical event in the entire population. There were very few events during follow-up, mainly related to repeat revascularization. We cannot exclude that collaterals may also have a protective effect on other outcomes, such as cardiac death and repeat revascularization. The sample size and number of events were too small to explore this further. It is likely that the reduction in perioperative MI will also influence the long-term outcome as documented after on-pump surgery and PCI. ${ }^{14-17}$ Also, we could not explore whether collateral grade influenced outcome.

To study the relation between collaterals and perioperative MI, we chose to first calculate the unadjusted OR of perioperative MI in the presence of collaterals followed by calculation of the adjusted OR. The latter was done after adjustment of variables assumed to have an effect on the outcome of interest and thus to confound the analysis. Comparison of the unadjusted and adjusted ORs discloses that collaterals indeed play an important protective role in the occurrence of perioperative MI. The difference between these ORs, however, indicates that other factors are involved. Still, when all variables were included in the analysis, collaterals proved protective against perioperative MI (OR $0.34,95 \%$ CI 0.14 to 0.84 ), which indicates the robustness of the finding.

In addition to the methods of analysis, the use of angiography for the definition of collaterals and the threshold value (Rentrop score $>1$ ) to discern their presence or absence may have influenced our observations. Quantitative assessment, which is considered superior to morphological assessment, was not used. ${ }^{18}$ We thus may have underestimated the protective effects of collaterals. Recent studies, however, report a good correlation between angiographic and functional methods of assessment in patients with stable angina referred for coronary angioplasty. ${ }^{19,20}$
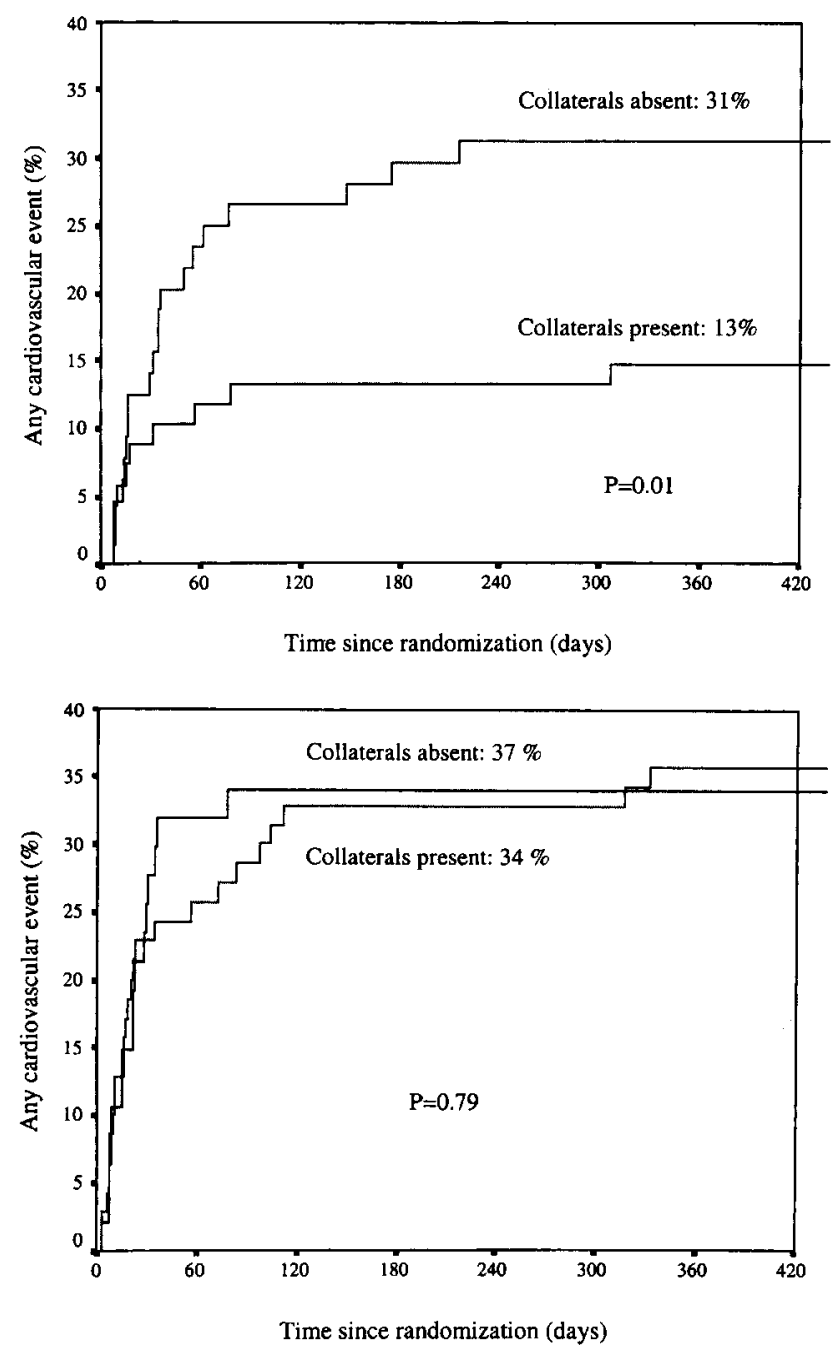

Kaplan-Meier estimates of proportion experiencing any event (composite of all-cause death, nonfatal stroke, nonfatal MI, and coronary reintervention) at 1 year after bypass surgery in patients with or without collaterals. Probability values were calculated with log-rank test. Top, Off-pump bypass surgery $(P=0.01)$; bottom, on-pump bypass surgery $(P=0.79)$.

The finding of the present study is in accordance with our hypothesis and is understandable from a pathophysiological point of view. ${ }^{21}$ The 2 groups stem from a randomized study, and collaterals were uniformly distributed over the 2 groups (49\% versus $51 \%)$. It thus appears that induction of complete cardiac arrest during on-pump CABG attenuates and even prohibits the potential protective role of collaterals, if present. During off-pump CABG, the target coronary is only temporally occluded to allow construction of the anastomoses on the beating heart. The findings of the present study may help guide patient management and risk stratification. Patients undergoing off-pump CABG but without collaterals may benefit from a number of measures such as ischemic myocardial preconditioning by short periods of repeated coronary occlusions, the use of intracoronary or aortocoronary shunting of blood, or a reduction of the coronary occlusion time by novel anastomosis techniques.22-26 After preconditioning, less CK-MB release during PCI and less troponin release 
during off-pump CABG have been reported. ${ }^{22,23}$ The safety of such novel surgical techniques has not been elucidated yet. Tissue formation due to endothelial damage at the site of the application may occur. Also, patients who undergo on-pump CABG may benefit from a number of measures, such as retrograde blood cardioplegia, cardioplegia administered down to the graft after placement, or grafting of the noncollateralized regions first to reduce the perioperative infarct rates.

We conclude that in a well-defined low-risk population, collaterals protect against perioperative MI during off-pump coronary bypass surgery and are associated with a better 1 -year outcome. This is not found in patients who undergo on-pump surgery.

\section{Acknowledgment}

The Octopus Study was funded entirely by grant OG 98-026 from the Netherlands National Health Insurance Council.

\section{References}

1. Habib GB, Heibig J, Forman SA, Brown BG, Roberts R, Terrin ML, Bolli R. Influence of coronary collateral vessels on myocardial infarct size in humans: results of phase I Thrombolysis In Myocardial Infarction (TIMI) trial: the TIMI Investigators. Circulation. 1991;83:739-746.

2. Charney R, Cohen M. The role of the coronary collateral circulation in limiting myocardial ischemia and infarct size. Am Heart J. 1993;126: 937-945.

3. Sabia PJ, Powers ER, Ragosta M, Sarembock IJ, Burwell LR, Kaul S. An association between collateral blood flow and myocardial viability in patients with recent myocardial infarction. N Engl J Med. 1992;327: 1825-1831.

4. Antoniucci D, Valenti R, Moschi G, Migliorini A, Trapani M, Santoro GM, Bolognese L, Cerisano G, Buonamici P, Dovellini EV. Relation between preintervention angiographic evidence of coronary collateral circulation and clinical and angiographic outcomes after primary angioplasty or stenting for acute myocardial infarction. Am J Cardiol. 2002; 89:121-125.

5. Cohen M, Rentrop KP. Limitation of myocardial ischemia by collateral circulation during sudden controlled coronary artery occlusion in human subjects: a prospective study. Circulation. 1986;74:469-476.

6. Pijls NH, Bech GJ, el Gamal MI, Bonnier HJ, De Bruyne B, Van Gelder B, Michels HR, Koolen JJ. Quantification of recruitable coronary collateral blood flow in conscious humans and its potential to predict future ischemic events. J Am Coll Cardiol. 1995;25:1522-1528.

7. Billinger M, Kloos P, Eberli FR, Windecker S, Meier B, Seiler C. Physiologically assessed coronary collateral flow and adverse cardiac ischemic events: a follow-up study in 403 patients with coronary artery disease. J Am Coll Cardiol. 2002;40:1545-1550.

8. Detter C, Reichenspurner H, Boehm DH, Thalhammer M, Schutz A, Reichart B. Single vessel revascularization with beating heart techniques: minithoracotomy or sternotomy? Eur J Cardiothorac Surg. 2001;19: 464-470.

9. Nathoe HM, van Dijk D, Jansen EW, Suyker WJ, Diephuis JC, van Boven WJ, de la Riviere AB, Borst C, Kalkman CJ, Grobbee DE, Buskens E, de Jaegere PP, for the Octopus Study Group. A comparison of on-pump and off-pump coronary bypass surgery in low-risk patients. $N$ Engl J Med. 2003;348:394-402.

10. Rentrop KP, Cohen M, Blanke H, Phillips RA. Changes in collateral channel filling immediately after controlled coronary artery occlusion by an angioplasty balloon in human subjects. J Am Coll Cardiol. 1985;5: 587-592.

11. van Liebergen RA, Piek JJ, Koch KT, de Winter RJ, Schotborgh CE, Lie KI. Quantification of collateral flow in humans: a comparison of angiographic, electrocardiographic and hemodynamic variables. J Am Coll Cardiol. 1999;33:670-677.

12. Bendz R, Strom S. Diagnostic significance of serum CK-MB elevations following surgical damage to skeletal muscles. Scand J Thorac Cardiovasc Surg. 1981;15:199-204.

13. Serruys PW, Unger F, Sousa JE, Jatene A, Bonnier HJ, Schonberger JP, Buller N, Bonser R, van den Brand MJ, van Herwerden LA, Morel MA, van Hout BA, for the Arterial Revascularization Therapies Study Group. Comparison of coronary-artery bypass surgery and stenting for the treatment of multivessel disease. N Engl J Med. 2001;344:1117-1124.

14. Costa MA, Carere RG, Lichtenstein SV, Foley DP, de Valk V, Lindenboom W, Roose PC, van Geldorp TR, Macaya C, Castanon JL, Fernandez-Avilez F, Gonzales JH, Heyer G, Unger F, Serruys PW. Incidence, predictors, and significance of abnormal cardiac enzyme rise in patients treated with bypass surgery in the arterial revascularization therapies study (ARTS). Circulation. 2001;104:2689-2693.

15. Steuer J, Horte LG, Lindahl B, Stahle E. Impact of perioperative myocardial injury on early and long-term outcome after coronary artery bypass grafting. Eur Heart J. 2002;23:1219-1227.

16. Marso SP, Bliven BD, House JA, Muehlebach GF, Borkon AM. Myonecrosis following isolated coronary artery bypass grafting is common and associated with an increased risk of long-term mortality. Eur Heart J. 2003; $24: 1323-1328$

17. Brener SJ, Ellis SG, Schneider J, Topol EJ. Frequency and long-term impact of myonecrosis after coronary stenting. Eur Heart J. 2002;23: $869-876$.

18. Seiler C, Fleisch M, Billinger M, Meier B. Simultaneous intracoronary velocity- and pressure-derived assessment of adenosine-induced collateral hemodynamics in patients with one- to two-vessel coronary artery disease. J Am Coll Cardiol. 1999;34:1985-1994.

19. Werner GS, Ferrari M, Heinke S, Kuethe F, Surber R, Richartz BM, Figulla HR. Angiographic assessment of collateral connections in comparison with invasively determined collateral function in chronic coronary occlusions. Circulation. 2003;107:1972-1977.

20. Van Royen N, Voskuil M, Hoefer I, Jost M, de Graaf S, Hedwig F, Andert JP, Wormhoudt T, Hua J, Hartmann S, Bode C, Buschman I, Schaper W, van der Neut R, Piek J, Pals S. CD44 regulates arteriogenesis in mice and is differentially expressed in patients with poor and good collateralization. Circulation. 2004;109:1647-1652.

21. Buschmann I, Schaper W. The pathophysiology of the collateral circulation (arteriogenesis). J Pathol. 2000;190:338-342.

22. Cribier A, Korsatz L, Koning R, Rath P, Gamra H, Stix G, Merchant S, Chan C, Letac B. Improved myocardial ischemic response and enhanced collateral circulation with long repetitive coronary occlusion during angioplasty: a prospective study. J Am Coll Cardiol. 1992;20:578-586.

23. Laurikka J, Wu ZK, Iisalo P, Kaukinen L, Honkonen EL, Kaukinen S, Tarkka MR. Regional ischemic preconditioning enhances myocardial performance in off-pump coronary artery bypass grafting. Chest. 2002; 121:1183-1189.

24. Yeatman M, Caputo M, Narayan P, Ghosh AK, Ascione R, Ryder I, Angelini GD. Intracoronary shunts reduce transient intraoperative myocardial dysfunction during off-pump coronary operations. Ann Thorac Surg. 2002;73:1411-1417.

25. van Aarnhem EE, Nierich AP, Jansen EW. When and how to shunt the coronary circulation in off-pump coronary artery bypass grafting. Eur J Cardiothorac Surg. 1999;16(suppl 2):S2-S6.

26. Suyker WJL, Buijsrogge MP, Suyker PTW, Verlaan CWJ, Borst C, Gründeman PF. Stapled coronary anastomosis with minimal intraluminal artifact: the S2 Anastomotic System in the off-pump porcine model. J Thorac Cardiovasc Surg. 2004;127:498-503. 